\title{
Trends in the Content of Modern Women's Writing and Their Effect on Modern Arabic Women's Writing
}

\author{
Mahmoud Naamneh
}

\section{Saleem Abu Jaber}

Under the yoke of patriarchal societies women were taboo and society did not consider them fit for creative writing. ${ }^{1}$ For millennia women lived under patriarchal exclusion, but when women began to write in the modern age this changed; women began to free themselves from their bonds and to write. Initially they wrote mainly about freedom, as the fundamental concept that had been aborted form many long years. ${ }^{2}$

Women were oppressed for many ages and were denied the right to express themselves and to engage in original writing, under the pretext that they were weak and incapable of contributing anything to literature. Even today women's artistic output tends to be marginalized, accused of mental debility and considered inferior. This is especially true of the Arab world, where no awareness exists of the true creative abilities of women. ${ }^{3}$

Many women poets, including young women still at the beginning of their literary careers, have produced texts of considerable originality through which they were able to present a reliable picture of many of the injustices to which women are exposed in their society. ${ }^{4}$ Women used writing and confession as the first step in their liberation from the many restrictions that had threatened their very existence as women for so long. The spokesperson for women writers has written: "We write in order to regain what we have lost and what was stolen from us unjustly. We write to stop this". ${ }^{5}$

Women thus tended in their writings to overcome the first obstacle, without yet producing original works, namely the freedom to write, a freedom that gave them the strength to fight against the despicable and backward image of women in antiquity as well as in modern times, an image of a human being in shackles even in the enlightened West. Even Charles Baudelaire, an epitome of modernism and the new age, still considers women to be something forbidden, an evil form or worse:

0 woman

0 queen of sin

$O$ vile majesty

0 exalted disgrace 6

\footnotetext{
${ }^{1}$ See al-Ghadhdhāmī, 196, 9.

2 See al-Qurashī, 2000, 56.

${ }^{3}$ See the Ministry of Culture of the Hashemite Kingdom of Jordan, 1997, 9.

${ }^{4}$ See Raḍwān, 2004, 126.

5 See Mustaghānimī, 1993, 105.

${ }^{6}$ See Baudelaire, 1989, 88.
} 
Because of this, women writers in the East and the West, in modern as well as in reactionary lands, used their freedom as the starting point for writing.

Women lived in the shadow of patriarchy and of men who dominated societies for a very long time; they suffered from marginalization and inferiority especially in the domains of culture and writing. Silence was the culture that dominated the society of women, while men controlled even culture. ${ }^{7}$

Despite this men and male society have a strong presence in women's literature and constitute important themes in it. This is the case due to the fact that the first voices in women's literature were affected by rational liberalism and socialist secularism, ${ }^{8}$ which believed in the need for equality between the sexes. For this reason men entered spontaneously into the earliest feminine sentiment that answered the first intellectual calls for equality. Critics call such men at this stage of feminine writing "transitional protagonists". 9

However, we should first speak about the image of men in ancient women's literature. As we noted above, the medieval Arab writer Ibn Tayfür quoted Arab women writers who composed texts with their own special language and their own special feminine characteristics. But even this literature makes its primary character a man. Here we shall quote one of the Arab women writers mentioned by Ibn Tatfūr, whose name was Umm Mu'abbad: ${ }^{10}$

I saw a man of the utmost purity, of shining face, good morals, not disfigured by a big belly nor ridiculed by thinness. Indeed, his eyes are dark, his eyebrows are bushy, his voice is raucous, his neck is radiant and in his beard is. In his eyes black contrasts with white, his black eyes have beautiful lashes, his eyebrows grow together. When he is silent he is dignified and when he speaks he is truly magnificent. He is the most beautiful and most brilliant of people from afar and the sweetest and best from close up. His speech is sweet, neither insignificant nor prattle.

In short, even in early Arab women's writings men are presented in a very positive light and are given a central position, as can be seen in the preceding description, where the man is depicted as the epitome of perfection. It may be said, in fact, that the woman who wrote this texts describes the perfect man as presented in Plato's Republic.

The Arab critic Jūrj Ṭarābīshī distinguishes two types of men in Arab women's literature, Western and Arab. Both are present in this literature, each possessing their own morphological features, projections and symbolisms, beginning with the representation of society and its mode of thought. ${ }^{11}$ Arab women who write find themselves "besieged" at every level, in their existence, their value, their freedom and their writing. The male's authority follows them everywhere; they are therefore in dire need of expressing their desire for equality with men by exposing in writing their unjust treatment and oppression by their society. ${ }^{12}$

Arab women address men audaciously in their poems and very courageously tell them that they refuse to submit to their authority. They do not plead with men, but speak to them from a

\footnotetext{
7 See Magadleh, 2011, 28.

8 See Farrāj, 1980, 14.

9 Ibid., 16.

11 See Ṭarābīshī, 1985, 6-8.

12 See Raḍwān, 2004, 61.
} 
position of self-respect, not as concubines or mothers as in the past, not as a mere means for satisfying men's sexual urges as was the case in the ignorant past. They rebel against the male view of women as objects of lust. However, despite all this, women in their poems express very different, even contradictory, feelings with respect to the nature of the relations that they would like with members of the opposite sex. On one hand they refuse to be subordinate and submissive to men, who in their view represent a male-dominated society that is hostile to their own feminine nature, who abhor having to belong to men and who find themselves unable to obtain their independence and freedom in a society that still insists on thwarting all their efforts to obtain their rights under the pretext that all women have someone who speaks for them and who forms their special mental world for them.

On the other hand, Arab women poets constantly admit in their writings that they need this denier of their rights as support for them, as their partner in life. They need men's love. Thus despite everything Arab women still carry in their hearts the spirit of oriental women, who view men as their strong protectors in time of trouble, who can help them overcome the difficulties that may stand in their way. They thus realize that they cannot escape their oriental nature and their need for a man to stand by her and help her with strength and determination to proceed with their lives. ${ }^{13}$

Women (poets) do not hesitate to speak about their emotions to their men and to express what they feel towards them. In their poems they write about their love and passion towards men, about how they suffer when they are far away, breaking down the walls and doing away with all boundaries between men and women.

A woman's feelings change with the changes in the relationship. One woman poet wrote about her lover's harshness, his inscrutability and his hidden feelings, until in the end she rebelled against her love and her lover.

Thus the kind of relationship a woman has with a man, as described by Arab women poets in their verses, differs from one poet to another and from one poem to another, depending on the poet's personality, her awareness of women's issues and her personal needs and psychological makeup.

Original writing was the interpreter through which modern women were able to express their existential and feminine problems. One of the most frequent topics in women's literature is writing itself; these new women wrote about the problem of creative writing, in a kind of metawriting, to use a term taken from contemporary literary criticism.

As part of their meta-writing women writers declared that women have a unique literary identity that differs completely from the identity and language of male writing. Literary critics judged this to be a sign of intellectual and artistic maturity, especially after women mastered their language, produced new artistic elements to use in their writings and used new techniques which they introduced into women's literature. ${ }^{14}$

13 Ibid., 63-64.

14 See Mujādala, 2011, 37-38. 
One theme that women poets use to attract the reader's attention is writing as a mirror of themselves, that is, writing about writing. Women poets write about themselves and their poetic experience as they use writing in order to express themselves. ${ }^{15}$

This discussion of the writings of Arab women poets brings us back to our point of departure. Women poets write about their poetic experiences and about themselves as poets who constantly stress the necessity of paying attention to women's problems and the crises they experience due to the fact that they live in a discriminatory society that robs them of their rights. Their writing affords them shelter and their words create a bridge with the external world, a means by which they try to pass on their "rebellious" poetic message to their society.

In short, women writers make writing the topic on which they write, in an attempt to place themselves at the center as women, or as a voice that differs from that of men, by focusing on their own difficulties in writing and their efforts to create a feminine language and poetics, aimed at defining their identity and the features of their feminine personality.

In the context of meta-poetics a poet may employ the device of addressing the reader (who can also be one of the protagonists about whom she writes), either inside the poetic text or on the margin. The latter takes the form of comments which the poet writes in order to help the reader understand aspects of the poem by explaining its background and the poet's own circumstances.

Writing that mirrors itself or writing about writing of necessity requires of the poet that she possess self-awareness as a woman and as a poet. She presents her problems as a woman in her literary/poetic works; in order to do this she must be fully aware of her own uniqueness and her true abilities. Her success in this depends on whether she possesses a comprehensive ability to discover the close links between her problems and the problems of her society as a whole and her place within society, in addition to her experiences at the personal and human level, in order for her to speak frankly about her feminine self, and her writing experiences.

The increasing conservatism in Arab societies has been accompanied by great vigilance on the part of women writers, who proposed new standards for their striving towards freedom under circumstances that from the outside seem conservative and overly authoritative. ${ }^{16}$

Many women poets have compared the act of writing to giving birth to a child, telling of the pains that accompany them as they write about their distressing situation in their poetry. They become immersed in their own personal pain and speak about their own private poetic experience as reflected in the expressions and words that they use in speaking about writing in the meta-poetic context.

In ancient times women, to use one critic's expression, were a Scheherazade facing onethousand men, ${ }^{17}$ but did not rebel.

As soon as Arab women's literature emerged, rebellion appeared as a distinct theme in it. It was a rebellion expressed by the use of the appropriate feminine pronouns and grammatical

15 For more on meta-literature see Hamd, 2007.

16 See Khamīs, 1997, 140.

17 See Guach, 2007, 1-13. 
persons as an overt declaration of feminism. Through the use of such pronouns women became entities in women's literature, after they had previously been objects, even ephemeral objects at times. Women's writing, through this rebellion, thus created a unified self for women and came to be built basically on the female self. 18

The voices of feminine rebellion began to appear in Arab women's compositions especially after the publication of Laylā al-Ba'lbakkī's novel Ahā ahyā (I Live; 1985) and after the appearance of the writings of Colette Khūrī, Aḥlām Mustaghanimī, Ḥanān al-Shaykh, Laylā al'Uthmān, Najāḥ al-'Ațțār, Salwā Bakr, Munā Jabbūr, Nawāl al-Sa'dāwī and Siḥr Khalīfa. The writings of these women contained a voice of rebellion against men and attacked the triple taboo of religion, sex and auth(ity, especially in the novels Dhākirat al-jasad (The Body's Memory) ${ }^{19}$ and Fawdā al-hawāss (Chaos of Feelings) ${ }^{20}$ by the Moroccan women writer Ahlām Mustaghānimī, who dealt with the triple taboo in a transparent way that no women writer had dared to in the past.

The rebellious voices of these Arab women writers emerged as a response to the disturbed political situation in the, beginning with the fall of Palestine and continuing with the crises in the Arab world due to foreign colonialism. Very quickly numerous national issues, with Palestine at the heart, appeared. The female voice resonated with the national and political "rejection and rebellion" and founded its own feminine rejection and rebellion in writing. ${ }^{21}$

All-in-all rebellion was a distinctive feature of the writings of both Arab and Western women. It continued in later times as well, in the period of literary post-modernism. Below we shall note some of these expressions of rebellion in the poems of women writers.

\section{CONCLUSION}

Interest in women's writing originally awakened during the enlightenment period of literature, shortly before the emergence of modernism, during and after it, especially after gender movements came into being throughout the world, which tried to impose their feminist approach on society and demanded historical rights that women had been denied for long years. Among these rights: That women's voices appear in literature and in other fields of art, after males had imposed their cultural and literary presence for many centuries.

We shed light on the issues that concerned modern women writers, globally and in the Arab world and how they exploited all available literary techniques in order to present these issues from a feminine perspective. The main issue was freedom: In their literary compositions women made it clear that they lacked freedom both as writers and as human beings. They accused male dominance over women for this situation, viewing them as the cause of their marginalization with respect to rights and duties as well as in the field of creating writing.

We also discussed the image of the new, rebellious woman in global literature and showed that women as represented in women's literature appeared in the form of rebels and protesters. In the few works that presented women of the old type they were presented as submissive. In

\footnotetext{
18 See Kirām, 1978, 52-53.

19 See Abū Niḍāl, 2009, 43.

20 See Mustaghānimī, 1996.

21 See Jum`a, 2005, 20.
} 
their new role women in fact came in their writings to claim to be superior to men in life's various domains and not merely their equal.

\section{Sources}

Khūrī, Nidā’ (1987). U'linu laka șamtī. Acre: Mu’assasat al-aswār.

Idem (1992). Zannār al-rīh. Acre: Dā'irat al-thaqāfa al-'arabiyya.

Idem (1993). Thaqāfat al-nabīdh. no place of publication: Dā’irat al-thaqāfa al-'arabiyya.

Idem (1997). Ajmal al-ālihāt tabkī. Cairo: Markaz al-ḥaḍāra al-‘arabiyya.

Qarmān, Sucād (1994a). "Qașīdat rūyā". Mawāqif 8, 61-63.

Idem (1994b). "Qașīda li-ajl țifl”. Mawāqif 9, 60-62.

Idem (1995). Hanīn al-hizār. Shafācamr: Dār al-mashriq.

Idem (2000). “Qaṣīdat ahlā al-zunbuqāt". Mawāqif 14, 47-50.

Zāāhir, Munā (1997). Shahriyār al-'așr. Nazareth: Bayt al-kitāb.

Idem (2001). Laylakiyyāt. Nazareth: Venus Publications.

Idem (2003). Țacm al-tuffāh. Cairo: al-Hay’a al-mișriyya al-‘̄mma lil-kitāb.

Idem (2006). Așābi í. Beirut: al-Mu’assasa al-'arabiyya lil-dirāsāt wal-nashr.

Idem (2008). Khamìl kaslihā al-șabāḥī. Amman: Azmina lil-nashr.

\section{References}

Farrāj, 'Afîf (1980). Al-Hurriyya fi adab al-mar'a. Beirut: Mu’assasat al-abḥāth al-'arabiyya.

Al-Ghadhdhāmī, 'Abdullāh (1996). Al-Mar'a wal-lugha. Casablanca: al-Markaz al-thaqāfĩ al-'arabī.

Guach, Suzanne (2007). Liberating Shahrazad, Feminism, Post Colonialism and Islam. London: University of Minnesota Press.

Ḥamd, Muḥammad (2007). Al-Mītā-qașș fĩ al-riwāya al-'arabiyya: Uțrūḥat duktūrāh. Haifa: Haifa University.

Kirām, Zuhūr (1978). Al-Sard al-nisā'ī al-'arabī, muqāraba fĩ al-mafhūm wal-khițāb. Casablanca: al-Madāris lilnashr wal-tawzī'.

Ibn Ṭayfūr, Aḥmad (1999). Balāghāt al-nisā’’ ed. by Sa`īd al-Buqāīì. Beirut: Dār al-aḍwā’.

Jum‘a, Zaynab (2005). Șūrat al-mar’a fī al-riwāya, qirā’a jadīda fĩ riwāyāt Emily Nașrallāh. Beirut: al-Dār al'arabiyya lil-'ulūm.

Majadly, Haifa (2011). Humūm al-mar'a al-'arabiyya fi adab Laylā al-'Uthmān, qirä’a fì riwāyatay al-'Aș'as wa-Șamt al-firāshāt. Haifa: Academy of the Arabic Language.

Ministry of Culture of the Hashemite Kingdom of Jordan (1997). Khușūșiyyat al-ibdā'al-niswī. Jordan: Ministry of Culture.

Mustaghānimī, Aḥlām (1993). Dhākirat al-jasad. Beirut: Dār al-ādāb.

Idem (1996). Dhākirat al-jasad. Beirut: Dār al-ādāb.

Idem (1998). Fawḍā al-ḥawāss. Beirut: Dār al-ādāb.

Al-Qurashī, Sirḥān ‘Ālī (2000). Naș̣ al-mar’a min al-ḥikāya ilā kitābat al-ta’wīl. Syria: Dār al-madā.

Țarābīshī, Jūrj (1985). Ramziyyat al-mar’a fi al-riwāya al-‘arabiyya. Beirut: Dār al-țalī‘a.

Zabiyya, Khamīs (1997). Al-Kitāba al-unthūwiyya. Damascus: Dār al-madā. 